\title{
PENGARUH DISIPLIN DAN MOTIVASI DAN KINERJA PEGAWAI \\ DINAS PETERNAKAN DAN KESEHATAN HEWAN PROVINSI BENGKULU
}

\author{
Tito Irwanto \\ Tri Febrina Melinda \\ Fakultas Ekonomi Universitas Dehasen Bengkulu
}

\begin{abstract}
ABSTRAK
Tito Irwanto, Tri Febrina Melinda; Tujuan penelitian ini adalah untuk mengetahui pengaruh disiplin dan motivasi terhadap kinerja pegawai Dinas Peternakan dan Kesehatan Hewan Provinsi Bengkulu. Jenis penelitian yang digunakan dalam penelitian ini adalah kuantitatif. Pengumpulan data dengan menyebarkan kuesioner kepada pegawai Dinas Peternakan dan Kesehatan Hewan Provinsi Bengkulu berjumlah 100 pegawai menggunakan simpel random sampling. Metode Analisis yang digunakan dengan Analisis Regresi Berganda, Analisis Korelasi, Uji T, Uji F serta Uji Koefisien Determinasi $\left(\mathrm{R}^{2}\right)$. Hasil analisis menunjukkan bahwa disiplin dan motivasi berpengaruh positif terhadap kinerja pegawai.
\end{abstract}

\begin{abstract}
Tito Irwanto, Tri Febrina Melinda; The purpose of this study was to determine the effect of discipline and motivation to employee performance Department of Animal Husbandry and Animal Health Bengkulu Province. This type of research used in this research is quantitative. The collection of data by distributing questionnaires to employees of the Department of Animal Husbandry and Health Bengkulu province amounted to 100 employees using simple random sampling. The analysis method used by Multiple Regression Analysis, Correlation Analysis, T Test, F Test and Test The coefficient of determination $\left(R^{2}\right)$. The analysis showed that the discipline and motivation positive influence on employee performance.
\end{abstract}

\section{Key Word: Dicipline, Motivation and Performance}

\section{PENDAHULUAN}

Dinas Peternakan dan Kesehatan Hewan Provinsi Bengkulu merupakan salah satu dinas yang memberikan kontribusi besar bagi masyarakat di Provinsi Bengkulu. Perkembangan dinas Peternakan dan Kesehatan Hewan Provinsi Bengkulu ini dipengaruhi oleh sumber daya manusia yang ada didalamnya. Peran penting Sumber daya manusia ditunjukkan baik secara perorangan ataupun kelompok, dan sumber daya manusia merupakan salah satu penggerak jalannya kegiatan organisasi, perusahaan menjadi maju atau mundur di tentukan oleh sumber daya manusianya.

Berbagai macam cara untuk meningkatkan kinerja pegawai dalam sebuah organisasi yang memudahkan organisasi mencapai tujuan organisasi. Kinerja sendiri dapat diartikan hasil kerja yang dicapai oleh seseorang pegawai atau sekelompok pegawai dalam organisasi, sesuai dengan tanggung jawab dan wewenang masing-masing pegawai untuk mencapai tujuan organisasi yang tidak melanggar hukum dan sesuai dengan moral maupun etika. Jadi kinerja merupakan hal yang penting bagi pegawai, perusahaan atau organisasi. Kinerja pegawai dapat dipengaruhi oleh faktor-faktor yang berhubungan dengan pegawai maupun lingkungan organisai itu sendiri.

Disiplin merupakan salah satu faktor yang mempengaruhi kinerja pegawai, Penegakan kedisiplinan pegawai merupakan sesuatu yang penting bagi suatu organisasi, karena dengan adanya kedisiplinan akan membuat pekerjaan yang dilakukan semakin efektif dan efisien. Bila kedisiplinan tidak dapat ditegakkan, kemungkinan tujuan yang telah ditetapkan oleh suatu organisasi tidak dapat tercapai. 
Kedisiplinan adalah kesadaran dan kesediaan seseorang dalam mentaati semua peraturan organisasi dan norma sosial yang berlaku. (Hasibuan, 2001). Dari organisasi/ instansi sendiri juga berperan dalam mengelola pegawai agar mematuhi segala peraturan, norma yang telah ditetapkan oleh organisasi sehingga para pegawai bekerja dengan disiplin dan efektif.

Kedisiplinan pada hakikatnya adalah kemampuan untuk mengendalikan diri dalam bentuk tidak melakukan suatu tindakan yang tidak sesuai dan bertentangan dengan sesuatu yang telah ditetapkan dan melakukan sesuatu yang mendukung dan melindungi sesuatu yang telah ditetapkan. Dalam lingkungan kerja yang dikenal adalah disiplin kerja. Disiplin kerja merupakan kemampuan seseorang secara teratur, tekun secara terus-menerus dan bekerja sesuai dengan aturan-aturan yang berlaku dengan tidak melanggar aturan yang telah ditetapkan.

Disiplin kerja pegawai adalah persepsi pegawai terhadap sikap pegawai dalam hal ketertiban dan keteraturan diri yang dimiliki oleh pegawai dalam bekerja di organisasi tanpa merugikan dirinya, orang lain atau lingkungannya. Pegawai yang disiplin dapat diartikan sebagai seorang pegawai yang selalu datang dan pulang tepat pada waktunya, mematuhi semua peraturan organisasi, mengerjakan pekerjaan dan tugas-tugas dengan baik dengan penuh rasa tanggung jawab.

Seorang pemimpin harus memberikan contoh dan berusaha pegawai yang di pimpinnya mempunyai disiplin yang baik serta dapat memberikan motivasi kepada pegawainya dalam melaksanakan disiplin di dalam organisasi. Motivasi juga merupakan faktor penting dalam meningkatkan kinerja pegawai. Dengan adanya motivasi akan mendorong pegawai melaksanakan tugas dan kegiatannya dengan hasil yang terbaik. Motivasi kerja yang tinggi biasanya akan berdampak pada kepada inerja yang tinggi.

Dari penjelasan diatas maka penulis tertarik melakukan penelitian tentang disiplin dan motivasi dan kinerja pegawai Dinas Peternakan dan Kesehatan Hewan Provinsi Bengkulu.

\section{Landasan Teori \\ Manajemen Sumber Daya Manusia}

Sebelum menjelaskan pengertian manajemen sumber daya manusia terlebih dahulu akan dijelaskan tentang pengertian manajemen dan pengertian sumber daya manusia. Manajemen berasal dari kata to manage yang artinya mengurus, mengatur, melaksanakan dan mengelola (Gomes, 2009:1). Pengertian ini pada umumnya dikaitkan dengan aktivitas-aktivias perencanaan, pengorganisasian, pengendalian, penempatan, pengarahan, pemotivasian, komunikasi dan pengambilan keputusan yang dilakukan oleh setiap organisasi dengan tujuan untuk mengkoordinasi berbagai sumber daya yang dimiliki oleh perusahaan sehingga akan dihasilkan suatu produk atau jasa secara efisien.

Manajemen merupakan proses bagaimana membimbing, mengarahkan orang-orang atau kelompok dalam organisasi untuk mencapai tujuan yang telah direncanakan sebelumnya, seperti yang kemukakan oleh Fathoni (2006:7), menjelaskan: "Pengertian manajemen dapat disebut pembinaan, pengendalian, pengelolaan, kepemimpinan, ketatalaksanaan, yang merupakan proses kegairahan untuk mencapai tujuan yang telah ditentukan sebelumnya".

Manajemen merupakan suatu seni mengatur orang-orang untuk dapat menyelesaikan tanggung jawab yang dibebankan kepadanya sesuai dengan tujuan yang telah ditetapkan atau direncanakan sebelumnya. Hal ini sejalan dengan pengertian manajemen yang dikemukan oleh Follett dalam Handoko (2008:3), mengandung arti bahwa manajer mencapai tujuan-tujuan organisasi melalui pengaturan orang-orang lain untuk melaksanakan berbagai pekerjaan itu sendiri.

Dari pengertian di atas disimpulkan bahwa manajemen adalah suatu ilmu dan seni mengatur bagaimana membuat perencanaan, pengorganisasian, mengarahkan dan mengendalikan sumber daya yang ada baik sumber daya manusia maupun sumber daya lain yang menunjang pencapaian tujuan dari sebuah organisasi.

Untuk mencapai tujuan tersebut diperlukan sumber daya manusia yang handal, untuk mengatur atau memenij sumber daya manusia yang handal, seorang pimpinan harus mengerti 
tentang manajemen sumber daya manusia yang menangani kegiatan-kegiatan seperti penarikan, seleksi, pemberian kompensasi dan pelatihan karyawan.

Sumber daya manusia merupa orang-orang yang ada dan terlibat dalam suatu organisasi, seperti yang dijelaskan oleh Gomes (2009:1), sumber daya manusia merupakan:

"Suatu sumber daya yang terdapat dalam organisasi, meliputi semua orang yang melakukan aktivitas. Secara umum, sumber daya yang terdapat dalam organisasi bisa dikelompokkan atas dua macam, yakni: 1) sumber daya manusia (human resource) dan 2) sumber daya non manusia (non human resources, yang termasuk dalam sumber daya non manusia ini antar lain modal, mesin, teknologi, bahan-bahan (material) dan lain-lain".

Jadi secara sederhana pengertian manajemen sumber daya manusia adalah mengelola sumber daya manusia. Dari keseluruhan sumber daya yang tersedia dalam suatu organisasi, baik organisasi publik (pemerintah) maupun organisasi swasta, sumber daya manusialah yang paling penting dan sangat menentukan. Sumber daya manusia merupakan satu-satunya sumber daya yang memiliki akal, perasaan, keinginan, kemampuan, keterampilan, pengetahuan, dorongan, daya dan karya. Sumber daya manusia ini perlu dikelola sehingga akan bermanfaat sesuai dengan fungsinya masing-masing, untuk mengelola sumber daya manusia diperlukan manajemen sumber daya manusia.

Dessler (2010:5), menjelaskan bahwa manajemen sumber daya manusia adalah: "Kebijakan dan praktik menentukan aspek "manusia" atau sumber daya manusia dalam posisi manajemen, termasuk merekrut, menyaring, melatih, memberi penghargaan dan penilaian". Kiggundu dalam Gomes (2009:4), juga mendefinisikan manajemen sumber daya manusia adalah: "Pengembangan dan pemanfaatan personil (pegawai) bagi pencapaian yang efektif mengenai sasaran-sasaran dan tujuan-tujuan individu, organisasi, masyarakat, nasional dan internasional". Sedangkan menurut Tulus dalam Gomes (2009:6), manajemen sumber daya manusia adalah : "Perencanaan, pengorganisasia, pengarahan, dan pengawasan atas pengadaan, pengembangan, pemberian kompensasi, pengintegrasian, pemeliharaan dan pemutusan hubungan tenaga kerja dengan maksud untuk membantu mencapai tujuan organisasi, individu, dan masyarakat".

Pendapat lain tentang manajemen sumber daya manusia dikemukakan oleh Sedarmayanti (2005:6), adalah: “Seni untuk merencanakan, mengorganisasikan, mengarahkan, mengawasi, kegiatan sumber daya manusia atau pegawai dalam rangka mencapai tujuan organisasi". Sehingga dapat disimpulkan manajemen sumber daya manusia merupakan suatu proses terdiri dari :

a. Rekruitmen atau penarikan sumber daya manusia.

b. Seleksi sumber daya manusia.

c. Pengembangan sumber daya manusia.

d. Pemeliharaan sumber daya manusia.

e. Penggunaan sumber daya manusia.

Manajemen sumber daya manusia atau manajemen personalia yang merupakan penarikan, seleksi, pengembangan pemeliharaan dan penggunaan sumber daya manusia untuk mencapai tujuan yang telah direncanakan sebelumnya. Menurut Flippo (Handoko, 2008:3), manajemen personalia adalah: "Perencanaan, pengorganisasian, pengarahan dan pengawasan kegiatan-kegiatan pengadaan, pengembangan, pemberian kompensasi, pengeintegrasian, pemeliharaan dan pelepasan sumber daya manusia agar tercapai berbagai tujuan individu, organisasi dan masyarakat".

\section{Disiplin}

Secara etimologi, disiplin berasal dari bahasa latin "disipel" yang berarti pengikut. Seiring dengan perkembangan jaman, kata tersebut mengalami perubahan menjadi "disipline" yang artinya kepatuhan atau yang menyangkut tata tertib. Disiplin kerja adalah suatu sikap ketaatan seseorang terhadap aturan/ketentuan yang berlaku dalam organisasi,yaitu : menggabungkan diri dalam organisasi itu atas dasar keinsafan, bukan unsur paksaan (Wursanto, 1987). 
Disiplin adalah sikap dari seseorang/kelompok orang yang senantiasa berkehendak untuk mengikuti/mematuhi segala aturan/keputusan yang ditetapkan. (M.Sinungan 1997). Dalam kesempatan yang berbeda, banyak pula ahli yang memberikan pengertian tentang disiplin, walaupun dengan sudut pandang yang berbeda. Salah satu diantara para ahli tersebut adalah Nitisemito (1996) yang menjelaskan bahwa disiplin adalah suatu sikap atau tingkah laku dan perbuatan yang sesuai dengan peraturan dari instansi perusahaan, baik yang tertulis maupun yang tidak tertulis.

Disiplin kerja adalah sikap mental yang tercermin dalam perbuatan atau tingkah laku seseorang, kelompok masyarakat berupa ketaatan (obedience) terhadap peraturan, norma yang berlaku dalam masyarakat. (Siagian 1996).

Menurut The Liang Gie (1981) disiplin diartikan sebagai suatu keadaan tertib dimana orang- orang tergabung dalam organisasi tunduk pada peraturan yang telah ditetapkan dengan senang hati. orang/sekelompok orang. Kedisiplinan adalah kesadaran dan ketaatan seseorang terhadap peraturan organisasi lembaga dan norma sosial yang berlaku. (Hasibuan, 2001).

Menurut Keith David dalam Mangkunegara (2001), menyatakan bahwa disiplin kerja dapat diartikan sebagai pelaksanan manajemen untuk memperteguh pedoman-pedoman organisasi.

Rumusan lain menyatakan bahwa disiplin merupakan tindakan manajemen mendorong para anggota organisasi memenuhi tuntutan berbagai ketentuan tersebut. Dengan perkataan lain, pendisiplinan pegawai adalah suatu bentuk pelatihan yang berusaha memperbaiki dan membentuk pengetahuan, sikap dan perilaku karyawan sehingga para karyawan tersebut secara sukarela berusaha bekerja secara kooperatif dengan para karyawan yang lain serta meningkatkan prestasi kerjanya (Siagian, 2000).

Sedangkan pendapat Siswanto Sastrohadiwiryo (2003) disiplin kerja dapat didefinisikan sabagai suatu sikap menghormati, menghargai, patuh, dan taat terhadap peraturan-peraturan yang berlaku baik yang tertulis maupun tidak tertulis serta sanggup menjalankannya dan tidak mengelak untuk menerima sanksi-sanksinya apabila ia melanggar tugas dan wewenang yang diberikan kepadanya.

Kedisiplinan adalah kesadaran dan kesediaan seseorang menaati semua peraturan perusahaan dan norma-norma sosial yang berlaku. Kesadaran disini merupakan sikap seseorang yang secara sukarela menaati semua peraturan dan sadar akan tugas dan tanggung jawabnya. Jadi, dia akan mematuhi atau mengerjakan semua tugasnya dengan baik, bukan atas paksaan. Sedangkan kesediaan adalah suatu sikap, tingkah laku, dan perbuatan seseorang yang sesuai dengan peraturan perusahaan, baik yang tertulis maupun tidak tertulis (Hasibuan, 2000).

Tindakan disiplin itu sendiri adalah pengurangan yang dipaksakan oleh pimpinan terhadap imbalan yang diberikan oleh organisasi karena adanya suatu kasus tertentu. Tindakan disiplin ini tidak termasuk pemberhentian sementara atau penurunan jumlah tenaga kerja yang disebabkan oleh kejadian-kejadian perilaku khusus dari pegawai yang menyebabkan rendahnya produktivitas atau pelanggaran-pelanggaran aturan-aturan instansi.

Disiplin yang mantap pada hakekatnya akan tumbuh dan terpancar dari hasil kesadaran manusia. Disiplin yang tidak bersumber dari hati nurani manusia akan menghasilkan disiplin yang lemahdan tidak bertahan lama. Disiplin akan tumbuh dan dapat dibina melalui latihan, pendidikan atau penanaman kebiasaan dengan keteladanan-keteladanan tertentu, yang harus dimulai sejak ada dalam lingkungan keluarga, mulai pada masa kanak-kanak dan terus tumbuh berkembang dan menjadikannya bentuk disiplin yang semakin kuat (Prijodarminto, 1994)

Berdasarkan pendapat-pendapat tersebut diatas, dapat disimpulkan bahwa disiplin kerja pegawai merupakan sikap atau tingkah laku yang menunjukkan kesetiaan dan ketaatan seseorang atau sekelompok orang terhadap peraturan yang telah ditetapkan oleh instansi atau organisasinya baik yang tertulis maupun tidak tertulis yang tercermin dalam bentuk tingkah laku dan perbuatan pada suatu organisasi untuk mencapai suatu tujuan tertentu sehingga diharapkan pekerjaan yang dilakukan efektif dan efisien. 


\section{Tujuan Disiplin Kerja}

Secara umum dapat disebutkan bahwa tujuan utama disiplin kerja adalah demi kelangsungan organisasi atau perusahaan sesuai dengan motif organisasi atau perusahaan yang bersangkutan baik hari ini maupun hari esok. Menurut Siswanto Sastrohadiwiryo (2003) secara khusus tujuan disiplin kerja para pegawai, antara lain :

1. Agar para pegawai menepati segala peraturan dan kebijakan ketenagakerjaan maupun peraturan dan kebijakan organisasi yang berlaku, baik tertulis maupun tidak tertulis, serta melaksanakan perintah manajemen dengan baik.

2. Pegawai dapat melaksanakan pekerjaan dengan sebaik-baiknya serta mampu memberikan pelayanan yang maksimum kepada pihak tertentu yang berkepentingan dengan organisasi sesuai dengan bidang pekerjaan yang diberikan kepadanya.

3. Pegawai dapat menggunakan dan memelihara sarana dan prasarana, barang dan jasa organisasi dengan sebaik-baiknya.

4. Para pegawai dapat bertindak dan berpartisipasi sesuai dengan norma-norma yang berlaku pada organisasi.

5. Pegawai mampu menghasilkan produktivitas yang tinggi sesuai dengan harapan organisasi, baik dalam jangka pendek maupun jangka panjang.

Tujuan disiplin baik kolektif maupun perorangan yang sebenarnya adalah untuk mengarahkan tingkah laku pada realita yang harmonis. Untuk menciptakan kondisi tersebut, terlebih dahulu harus di wujudkan keselerasan antara hak dan kewajiban pegawai/pegawai.

\section{Jenis- jenis disiplin kerja}

T. Hani Handoko (2008) menggolongkan jenis-jenis disiplin antara lain :

1. Disiplin Preventif

Disiplin preventif merupakan kegiatan yang dilaksanakan dengan maksud untuk mendorong para karyawan agar sadar mentaati berbagai standar dan aturan, sehingga dapat dicegah berbagai penyelewengan atau pelanggaran. Yang utama dalam hal ini adalah ditumbuhkannya "self discipline" pada setiap karyawan tanpa kecuali.

2. Disiplin Korektif

Disiplin korektif merupakan kegiatan yang diambil untuk menangani pelanggaran yang terjadi terhadap aturan-aturan, dan mencoba untuk menghindari pelanggaran-pelanggaran lebih lanjut. Kegiatan korektif ini berupa suatu bentuk hukuman atau tindakan pendisiplinan (disciplinary action), yang wujudnya dapat berupa "peringatan" ataupun berupa "schorsing". Semua sasaran pendisiplinan tersebut harus positif, bersifat mendidik dan mengoreksi kekeliruan untuk tidak terulang kembali.

Sedangkan menurut Keith Davis dan John W. Newstrom dalam Triguno (1997), menyatakan bahwa disiplin mempunyai 3 (tiga) macam bentuk, yaitu:

1. Disiplin Preventif

Disiplin preventif adalah tindakan SDM agar terdorong untuk menaati standar atau peraturan. Tujuan pokoknya adalah mendorong SDM agar memiliki disiplin pribadi yang tinggi, agar peran kepemimpinan tidak terlalu berat dengan pengawasan atau pemaksaan, yang dapat mematikan prakarsa dan kreativitas serta partisipasi SDM.

2. Disiplin Korektif

Disiplin korektif adalah tindakan dilakukan setelah terjadi pelanggaran standar atau peraturan, tindakan tersebut dimaksud untuk mencegah timbulnya pelanggaran lebih lanjut. Tindakan itu biasanya berupa hukuman tertentu yang biasa disebut sebagai tindakan disipliner, antara lain berupa peringatan, skors, pemecatan.

3. Disiplin Progresif

Disiplin progresif adalah tindakan disipliner berulang kali berupa hukuman yang makin berat, dengan maksud agar pihak pelanggar bisa memperbaiki diri sebelum hukuman berat dijatuhkan.

Disiplin dapat dibedakan berdasarkan tingkatannya, yaitu (Prijodarminto, 1994):

1. Disiplin Pribadi 
Disiplin pribadi sebagai perwujudan disiplin yang lahir dari kepatuhan atas aturan-aturan yang mengatur perilaku individu.

2. Disiplin Kelompok

Disiplin kelompok sebagai perwujudan yang lahir dari sikap taat, patuh terhadap aturanaturan (hukum) dan norma-norma yang berlaku pada kelompok atau bidang-bidang kehidupan manusia.

3. Disiplin Nasional

Disiplin nasional yakni wujud disiplin yang lahir dari sikap patuh yang ditunjukkan oleh seluruh lapisan masyarakat terhadap aturan-aturan, nilai yang belaku secara nasional.

Dalam setiap organisasi atau perusahaan yang diinginkan adalah jenis disiplin preventif yang timbul dari diri sendiri atas dasar kerelaan dan kesadaran. Akan tetapi dalam kenyataan selalu mengatakan bahwa disiplin itu lebih banyak disebabkan adanya paksaan dari luar dan hak-hak karyawan sudah menjadi alat pengenalan yang tepat kepada disiplin karyawan, karena hak-hak karyawan seringkali merupakan masalah dalam kasus-kasus disiplin karyawan.

\section{Pendekatan Disiplin Kerja}

Sistem disiplin karyawan dapat dipandang suatu penerapan modifikasi perilaku untuk karyawan bermasalah atau karyawan yang tidak produktif. Disiplin yang terbaik adalah jelas disiplin diri, karena sebagian besar orang memahami apa yang diharapkan dari dirinya di pekerjaan dan biasanya karyawan diberi kepercayaan untuk menjalankan pekerjaannya secara efektif. Adapunpendekatan pendekatan dalam disiplin kerja karyawan (Mathis dkk, 2002) adalah :

\section{Pendekatan Disiplin Positif}

Pendekatan disiplin positif dibangun berdasarkan filosofi bahwa pelanggaran merupakan tindakan yang biasanya dapat dikoreksi secara konstruktif tanpa perlu hukuman. Dalam pendekatan ini fokusnya adalah pada penemuan fakta dan bimbingan untuk mendorong perilaku yang diharapkan, dan bukannya menggunakan hukuman (penalti) untuk mencegah perilaku yang tidak diharapkan.

Kekuatan pendekatan positif ini dalam disiplin adalah fokusnya pada pemecahan masalah. Juga, karena karyawan merupakan partisipan aktif selama proses tersebut, maka perusahaan yang menggunakan pendekatan ini cenderung memenangkan tuntutan hukum jika karyawan mengajukan tuntutan. Kesulitan utam dengan pendekatan positif terhadap disiplin adalah jumlah waktu yang sangat lama untuk melatih para supervisor dan manajer yang diperlukan.

2. Pendekatan Disiplin Progresif

Disiplin progresif melembagakan sejumlah langkah dalam membentuk perilaku karyawan. Kebanyakan prosedur disiplin progresif menggunakan peringatan lisan dan tulisan sebelum berlanjut ke PHK.

Dengan demikian, disiplin progresif menekankan bahwa tindakan-tindakan dalam memodifikasi perilaku akan bertambah berat secara progresif (bertahap) jika karyawan tetap menunujukkan perilaku yang tidak layak.

Ada tiga pendekatan disiplin menurut Mangkunegara (2001) yaitu:

1. Pendekatan Disiplin Modern

Pendekatan disiplin modern yaitu menemukan sejumlah keperluan atau kebutuhan baru di luar hukuman. Pendekatan ini berasumsi:

a. Disiplin modern merupakan suatu cara menghindarkan bentuk hukuman secara fisik.

b. Melindungi tuduhan yang benar untuk diteruskan pada proses hukuman yang berlaku.

c. Keputusan-keputusan yang semuanya terhadap kesalahan atau prasangka harus diperbaiki dengan mengadakan proses penyuluhan dengan mendapatkan fakta-faktanya.

d. Melakukan protes terhadap keputusan yang berat sebelah pihak terhadap kasus disiplin.

2. Pendekatan Disiplin dengan Tradisi

Pendekatan disiplin dengan tradisi, yaitu pendekatan dengan cara memberi hukuman.

Pendekatan ini berasumsi: 
a. Disiplin dilakukan oleh atasan kepada bawahan, dan tidak pernah ada peninjauan kembali bila telah diputuskan.

b. Disiplin adalah hukuman untuk pelanggaran, pelaksanaannya harus disesuaikan dengan tingkat pelanggaran.

c. Pengaruh hukuman untuk memberikan pelajaran kepada pelanggaran maupun kepada pegawai lainnya.

d. Peningkatan perbuatan pelanggaran diperlukan hukuman yang lebih keras.

e. Pemberian hukuman terhadap pegawai yang melanggar kedua kalinya harus diberi hukuman yang lebih berat.

3. Pendekatan Disiplin Bertujuan

Pendekatan disiplin bertujuan berasumsi:

a. Disiplin kerja harus dapat diterima dan dipahami oleh semua pegawai.

b. Disiplin bukanlah suatu hukuman, tetapi merupakan pembetulan perilaku.

c. Disiplin ditujukan untuk perbuatan perilaku yang lebih baik.

d. Disiplin pegawai bertujuan agar pegawai bertanggung jawab terhadap peraturannya.

\section{Motivasi}

Istilah motivasi (motivation) berasal dari bahsa latin, yakni movere yang berarti "menggerakkan" (to move). Motivasi mewakili proses-proses psikologikal, yang menyebabkan timbulnya, diarahkannya, terjadinya persistensi kegiatan-kegiatan yang sukarela (voolunter) yang diarahkan ketujuan tertentu (Mitchell, 1982 dalam Winardi, 2007). Motivasi adalah suatu kegiatan yang mendorong seorang individu untuk melakukan sesuatu yang diinginkan. Sesuatu yang diiginkan itu mungkin untuk kebaikan individu tersebut atau untuk orang yang memberi dorongan tadi, atau untuk keduanya (Prasetyo, 2006). Robbins, (2006) motivasi sebagai suatu proses yang ikut menentukan intensitas arah, dan ketekunan individu dalam usaha mencapai sasaran. Sedarmayanti (2008:233) juga mengungkapkan bahwa, "motivasi merupakan kesediaan mengeluarkan tingkat upaya tinggi kearah tujuan organisasi yang dikondisikan oleh kemampuan upaya itu untuk memenuhi kebutuhan individual."

Dari beberapa pengertian diatas pada hakekatnya motivasi merupakan daya dorong,keinginan, kebutuhan dan kemauan. Kebutuhan tersebut pada akibatnya akan mendasari perilakuseseorang untuk berbuat sesuatu. Seperti yang dikemukakan oleh Vance yang dikutip oleh Sudarwan (2004:15) mengungkapkan bahwa, "motivasi adalah perasaan atau keinginanseseorang yang berada dan bekerja pada kondisi tertentu untuk melaksanakan tindakan-tindakan yang menguntungkan dilihat dari prospektif pribadi dan terutama organisasi."

\section{Teori-Teori Motivasi}

Menurut Hasibuan (1999), teori-teori Motivasi diklasifikasikan/ dikelompokkan atas :

1) Teori Kepuasan (Content Theory)

Teori kepuasan ini mendasarkan pendekatannya atas faktorfaktor kebutuhan dan kepuasan inidividu yang menyebabkannya bertindak serta berperilaku dengan cara tertentu. Teori ini memusatkan perhatian pada faktor-faktor dalam diri orang yang menguatkan, mengarahkan, mendukung dan menghentikan perilakunya.

2) Teori Motivasi Proses (Proses Theory)

Teori motivasi proses ini pada dasarnya berusaha menjawab pertanyaan bagaimana menguatkan, mengarahkan, memelihara dan menghentikan perilaku individu, agar setiap individu bekerja sesuai dengan keinginan pimpinan. Bila diperhatikan secara mendalam, teori ini merupakan proses sebab dan akibat bagaimana seseorang bekerja serta hasil apa yang akan diperolehnya.

3) Teori Pengukuhan (Reinforcement Theory)

Teori ini didasarkan atas hubungan sebab dan akibat dari perilaku dengan pemberian kompensasi. Misalnya promosi tergantung dari prestasi yang selalu dapat dipertahankan. 
Sedangkan menurut Landy dan Becker dalam Nursalam (2002), mengelompokkan banyak pendekatan modern pada teori dan praktik menjadi 4 (empat) kategori yaitu:

1) Teori Kebutuhan

Teori kebutuhan memfokuskan pada yang dibutuhkan orang untuk hidup berkecukupan. Dalam praktiknya, teori kebutuhan berhubungan dengan bagian pekerja yang sedang dilakukan untuk

memenuhi kebutuhan. Individu dalam memenuhi kebutuhan hidupnya sehari-hari akan berusaha sebaik mungkin melakukan pekerjaannya, demi tercukupnya kebutuhanya tersebut.

2) Teori keadilan

Teori keadilan didasarkan pada asumsi bahwa faktor utama dalam motivasi pekerjaan adalah evaluasi individu atau keadilan dalam penghargaan yang diterima. Individu akan termotivasi kalau mereka mengalami kepuasan dan mereka terima dari upaya dalam proporsi dan dengan usaha yang mereka pergunakan.

3) Teori harapan

Menyatakan cara memilih dan bertindak dari berbagai alternatif tingkah laku, berdasarkan harapannya apakah ada keuntungan yang diperoleh dari tiap tingkah laku.

4) Teori penguat.

Teori penguatan yang dikaitkan dengan ahli psikologi B.f Skinner dengan temantemannya, menunjukkan bagaimana konsekuensi tingkah laku dimasa lampau yang mempengaruhi tindakan pada masa depan dalam proses belajar siklus.

\section{Perangsang Motivasi}

Agar seseorang mau dan bersedia melakukan seperti yang diharapkan, kadang kala perlu disediakan perangsang. Dalam motivasi perangsang ini dibedakan atas dua macam yakni: (Azwar, A 1998)

1. Perangsang Positif

Perangsang positif ialah imbalan yang menyenangkan yang disediakan untuk karyawan yang berprestasi. Rangsangan positif ini banyak macamnya, antara lain hadiah, pengakuan, promosi dan ataupun melibatkan karyawan tersebut pada kegiatan yang bernilai gengsi yang lebih tinggi.

2. Perangsang Negatif

Perangsang negatif ialah imbalan yang tidak menyenangkan berupa berupa hukuman bagi karyawan yang tidak berprestasi dan ataupun yang berbuat tidak seperti yang diharapkan. Macam perangsang yang negatif ini banyak pula jenisnya, antara lain denda, teguran, pemindahan tempat kerja (mutasi) dan ataupun pemberhentian. Tentu agar pekerjaan dapat berjalan dengan lancar, pemberian perangsang ini harus harus disesuaikan dengan kemampuan serta situasi dan kondisi yang dihadapi. Sesuatu yang bersifat terpaksa atau dilakukan secara berlebihan tidakkan mendatangkan hasil sebagaimana yang diharapkan.

\section{Faktor-faktor Yang Mempengaruhi Motivasi}

Saydam, (1996) faktor-faktor yang mempengaruhi motivasi yaitu:

1. Faktor Ekstern yang dapat mempengaruhi motivasi tersebut adalah :

a. Lingkungan kerja yang menyenangkan.

b. Kompensasi (Insentif) yang memadai.

c. Supervisi yang baik.

d. Adanya penghargaan dan prestasi.

e. Status dan tanggung jawab.

f. Peraturan yang berlaku.

2. Faktor Intern yang dapat mempengaruhi motivasi tersebut adalah :

a. Kematangan pribadi.

b. Tingkat pendidikan. 
c. Keinginan dan harapan pribadi.

d. Kebutuhan.

e. Kelelahan dan kebosanan.

f. Kepuasan kerja.

\section{Kinerja}

Kinerja dapat merupakan penampilan individu maupun kelompok kerja personil. Penampilan hasil kerja tidak terbatas kepada personil yang memangku jabatan fungsional maupun struktural di dalam organisasi (Ilyas, 2001). Kinerja berasal dari kata performance. Ada pula yang memberikan pengertian performance sebagai hasil kerja atau prestasi kerja, namun kinerja mempunyai makna yang lebih luas, bukan hanya hasil kerja termasuk bagaimana proses pekerjaan berlangsung (Wibowo, 2009). Menurut Kottze (2006) dalam Wibowo, (2009) kinerja adalah hasil dari aplikasi kombinasi antara sustaining dan accelerating leadership behavior.

Kinerja adalah hasil kerja secara kualitas dan kuantitas yang dicapai oleh seseorang karyawan dalam kemampuan melaksanakan tugas-tugas sesuai dengan tanggung jawab yang diberikan oleh atasan kepadanya. Selain itu, kinerja juga dapat diartikan sebagai suatu hasil dan usaha seseorang yang dicapai dengan adanya kemampuan dan perbuatan dalam situasi tertentu (Mangkunegara, 2000). Menurut Amstrong dan Baron (1998) dalam (Wibowo, 2009) kinerja merupakan hasil pekerjaan yang mempunyai hubungan kuat dengan tujuan strategis organisasi, kepuasan konsumen, dan memberikan kontribusi ekonomi.

\section{Indikator Kinerja}

Viethzal dan Fauzi (2004) pada umumnya terdapat 5 (lima) macam indikator kinerja digunakan yaitu:

1. Input, mengukur sumber daya yang diinvestasikan dalam suatu proses, program, maupun aktivitas untuk menghasilkan keluaran (output maupun outcome). Indikator ini mengukur jumlah sumber daya seperti anggaran (dana), sumber daya manusia, informasi, kebijaksanaan/peraturan perundang-undangan dan sebagainya yang dipergunakan untuk melaksanakan kegiatan. Dengan meninjau distribusi sumber daya, suatu lembaga dapat menganalisis apakah alokasi sumber daya yang dimiliki telah sesuai dengan rencana yang telah ditetapkan.

2. Output adalah sesuatu yang diharapkan langsung dicapai dari sesuatu kegiatan yang dapat berupa fisik dan atau non fisik. Indikator ini digunakan untuk mengukur output yang dihasilkan dari suatu kegiatan. Dengan membandingkan output yang direncanakan dan yang betul-betul terealisir, instansi dapat menganalisis sejauh mana kegiatan terlaksana sesuai dengan rencana. Indikator output hanya dapat menjadi landasan untuk menilai kemajuan suatu kegiatan apabila tolok ukur dikaitkan dengan sasran-sasaran kegiatan yang terdefinisi dengan baik dan terukur. Oleh sebab itu, indikator output harus sesuai dengan lingkup dan kegiatan instansi.

3. Outcome, adalah segala sesuatu yang mencerminkan berfungsinya output (efek langsung) pada jangka menengah. Dalam banyak hal, informasi yang diperlukan untuk mengukur outcome seringkali tidak lengkap dan tidak mudah diperoleh. Oleh karena itu, setiap instansi perlu mengkaji berbagai pendekatan untuk mengukur outcome dari output suatu kegiatan. Pengukuran indikator outcome seringkali rancu dengan pengukuran indikator output. Contohnya, penghitungan jumlah bibit unggul yang dihasilkan oleh sesuatu kegiatan merupakan tolok ukur output. Akan tetapi perhitungan besar produksi per hektar yang dihasilkan oleh bibit-bubit unggul tersebut merupakan indikator outcome.

4. Benefit, menggambarkan manfaat yang diperoleh dari indikator outcome. Benefit (manfaat) tersebut pada umumnya tidak segera tampak. Setelah beberapa waktu kemudian, yaitu dalam jangka menengah atau jangka panjang dari benefitnya tampak. Indikator benefit menunjukan hal-hal yang diharapkan untuk dicapai bila output dapat diselesaikan dan berfungsi dengan optimal (tepat lokasi dan tepat waktu). 
5. Impact memperlihatkan pengaruh yang ditimbulkan dari benefit yang diperoleh. Seperti halnya indikator benefit, indikator impact juga baru dapat diketahui dalam jangka waktu menengah atau jangka panjang. Indikator impact menunjukan dasar pemikiran dilaksanakannya kegiatan yang menggambarkan aspek makro pelaksanaan kegiatan, tujuan kegiatan secara sektoral, regional dan nasional.

Kinerja merupakan perwujudan yang dilakukan oleh pegawai yang biasanya dipakaisebagai dasar penilaan terhadap pegawai atau organisasi.Kinerja yang baik merupakan langkahmenuju tercapainya tujuan organisasi.Oleh karena itu kinerja merupakan penentu dalam tercapaitujuan organisasi.Sehingga perlu diupayakan peningkatan kinerja, walaupun hal itu tidaklahmudah karena banyak factor yang menyebabkan tinggi rendahnya kinerja seseorang.Banyak teori yang mengemukakan mengenai faktor yang mempengaruhi kinerja baik secara pribadi yang mempunyai karakteristik tang bersifat fisik maupun kejiwaan. Gomes (2002:142) menyatakan bahwa kriteria pengukuran kinerja berdasarkan perilakuyang sfesifik adalah sebagai berikut:

a. Quantity of work, yaitu jumlah tenaga kerja yang dilakukan dalam suatu periode waktutertentu.

b. Quality of work, yaitu kualitas kerja yang dicapai berdasarkan syarat-syaratkesiapannya.

c. Job knowledge, yaitu luasnya pengetahuan mengenai pekerjaan dan ketrampilannya.

d. Creativeness,yaitu keaslian gagasan yang dimunculkan dan tindakan untuk menyelesaikan persoalan-persoalan yang timbul.

e. Cooperation,yaitu kesediaan untuk bekerjasama dengan orang lain (sesama anggota organisasi).

f. Dependability, yaitu kesadaran berdisiplin dan dapat dipercaya dalam kehadiran dan penyelesaiaan pekerjaan.

g. Initiative, yaitu semangat untuk melaksanakan tugas-tugas baru dan dalammemperbesar tanggungjawabnya.

h. Personal qualities, yaitu menyangkut kepribadian, kepemimpinan, keramahtamahan dan integritas pribadi.

\section{Kerangka Penelitian}

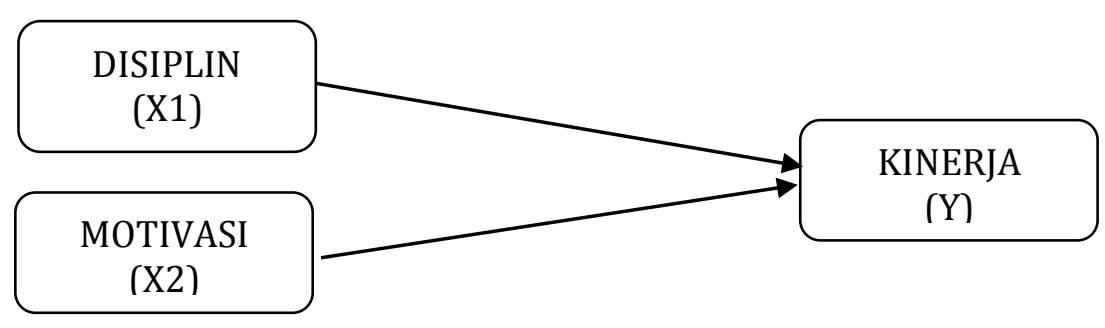

Gambar 1. Kerangka Penelitian

\section{Hipotesis}

Hipotesis yang dikemukakan penulis adalah sebagai berikut:

1. Diduga Disiplin mempunyai pengaruh secara positif terhadap Kinerja.

2. Diduga Motivasi mempunyai pengaruh secara positif terhadap Kinerja.

\section{HASIL DAN PEMBAHASAN Analisis Regresi Linear Berganda}

Dalam penelitian ini untuk mengetahui pengaruh disiplin dan motivasi terhadap kinerja pegawai Dinas Peternakan dan Kesehatan Hewan Provinsi Bengkulu menggunakan analisis statistik regresi linear berganda Untuk mengetahui besarnya pengaruh yang ada dengan persamaan sebagai berikut: 
$\mathbf{Y}=\mathbf{a}+\mathbf{b}_{1} \mathbf{X}_{1}+\mathbf{b}_{2} \mathbf{X}_{2}+\mathbf{e}$ Sugiyono (2009:282)

Dimana:

$\mathrm{Y} \quad$ = Kinerja pegawai Dinas Peternakan dan Kesehatan Hewan Provinsi Bengkulu

a $\quad=$ Nilai Konstan

$\mathrm{X}_{1} \quad=$ Disiplin

$\mathrm{X}_{2} \quad$ = Motivasi

$\mathrm{b}_{1}, \mathrm{~b}_{2}=$ Kofisien regresi

$\mathrm{e} \quad=$ Kesalahan pengganggu

Dengan bantuan menggunakan SPSS versi 16.0. dan pengolahan data yang diperoleh dari hasil rekapitulasi jawaban responden atas kuesioner yang disebarkan kepada pegawai Dinas Peternakan dan Kesehatan Hewan Provinsi Bengkulu sebanyak 100 orang. Berdasarkan penelitian ini maka variabel yang dianalisis adalah variabel independent terdiri dari Disiplin (X1) dan Motivasi (X2) serta variabel dependen (Y) adalah kinerja.

Tabel 1. Analisis Regresi Linier Berganda

Coefficients ${ }^{\mathrm{a}}$

\begin{tabular}{|c|c|c|c|c|c|c|}
\hline \multirow{2}{*}{\multicolumn{2}{|c|}{ Model }} & \multicolumn{2}{|c|}{ Unstandardized Coefficients } & \multirow{2}{*}{$\begin{array}{c}\begin{array}{c}\text { Standardized } \\
\text { Coefficients }\end{array} \\
\text { Beta }\end{array}$} & \multirow[b]{2}{*}{$\mathrm{t}$} & \multirow[b]{2}{*}{ Sig. } \\
\hline & & B & Std. Error & & & \\
\hline \multirow[t]{3}{*}{1} & (Constant) & 12.240 & 1.824 & & 6.712 & .000 \\
\hline & Disiplin & .168 & .069 & .231 & 2.451 & .016 \\
\hline & Motivasi & .266 & .083 & .302 & 3.207 & .002 \\
\hline
\end{tabular}

a. Dependent Variable: Kinerja

Dari Tabel 1. diperoleh persamaan regresi linier berganda sebagai berikut:

$Y=12.240+0,168 X_{1}+0,266 X_{2}+e$

Dari persamaan tersebut dapat dijelaskan bahwa:

1. Variabel disiplin dan motivasi mempunyai arah koefisien yang bertanda positif terhadap kinerja karyawan.

2. Koefisien disiplin memberikan nilai sebesar 0,168 yang berarti bahwa jika disiplin semakin baik dengan asumsi variabel lain tetap maka kinerja karyawan akan mengalami peningkatan.

3. Koefisien motivasi memberikan nilai sebesar 0,266 yang berarti bahwa jika motivasi semakin baik dengan asumsi variabel lain tetap maka kinerja karyawan akan mengalami peningkatan.

Pengujian Hipotesis

Uji Serentak(Uji F)

Tabel 2. Analisis Uji Serentak (Uji F)

ANOVA $^{b}$

\begin{tabular}{|ll|r|r|r|r|r|}
\hline Model & & Sum of Squares & df & Mean Square & F & Sig. \\
\hline 1 & Regression & 95.425 & 2 & 47.712 & 9.967 & $.000 \mathrm{a}$ \\
& Residual & 464.335 & 97 & 4.787 & & \\
& Total & 559.760 & 99 & & & \\
\end{tabular}

a. Predictors: (Constant), Motivasi, Disiplin

b. Dependent Variable: Kinerja 
Uji seretak (uji F) menghasilkan nilai F hitung sebesar 9.967. Pada derajat bebas 1 (df1) = jumlah variabel $-1=3-1=2$, dan derajat bebas $2(\mathrm{df} 2)=\mathrm{n}-\mathrm{k}-1=100-2-1=97$, dimana $\mathrm{n}$ $=$ jumlah sampel, $\mathrm{k}=$ jumlah variabel independent, nilai $\mathrm{f}$ tabel pada taraf kepercayaan signifikansi 0,05 adalah 9.967 dengam demikian $\mathrm{F}$ hitung $=9,967>\mathrm{F}$ tabel $=3,090$. tingkat signifikansi 0,000.

Karena probabilitasnya signifikansi jauh lebih kecil dari sig $<0,05$, maka model regresi dapat dipergunakan untuk memprediksi kinerja pegawai pada Dinas Peternakan dan Kesehatan Hewan Provinsi Bengkulu atau dapat dikatakan bahwa vaiabel disiplin dan motivasi secara bersama-sama berpengaruh terhadap kinerja pegawai Dinas Peternakan dan Kesehatan Hewan Provinsi Bengkulu.

\section{Koefisien Determinasi}

Pedoman dalam interprestasi koefisien atau seberapa besar pengaruh variabelvariabel bebas (Independen) terhadap variabel terikat (Dependen) sebagai berikut:

Tabel 3. Koefisien Determinasi

\begin{tabular}{|c|c|}
\hline Interval Koefisien & Tingkat Hubungan \\
\hline $0,000-0,199$ & Sangat rendah \\
\hline $0,200-0,399$ & Rendah \\
\hline $0,400-0,599$ & Sedang \\
\hline $0,600-0,799$ & Kuat \\
\hline $0,800-1,000$ & Sangat Kuat \\
\hline
\end{tabular}

Sumber: Sugiyono (2012:250)

Tabel 4. Analisis Korelasi

\begin{tabular}{|l|r|r|r|r|}
\hline Model & R & \multicolumn{1}{|c|}{ R Square } & Adjusted R Square & Std. Error of the Estimate \\
\hline 1 & $.413 \mathrm{a}$ & .170 & .153 & 2.18791 \\
\hline
\end{tabular}

a. Predictors: (Constant), Motivasi, Disiplin

Pada hasil penelitian pada tabel 4. ditemukan bahwa hubungan antara disiplin dan motivasi kerja dengan kinerja pegawai Pada Dinas Peternakan dan Kesehatan Hewan Provinsi Bengkulu adalah sedang sebesar $(R=0,413)$. Koefisien determinasi atau angka $R$ square $\left(R^{2}\right)$ adalah sebesar 0,170 atau $17 \%$. Hal ini berarti $17 \%$. variasi variabel kinerja karyawan dapat dijelaskan oleh variabel disiplin dan motivasi, sedangkan sisanya sebesar $83 \%$ diterangkan oleh variabel lain yang tidak diajukan dalam penelitian ini

\section{Uji t}

Dari tabel 1. Dapat diketahui pengaruh variabel $\mathrm{X}$ terhadap variabel $\mathrm{Y}$ secara parsial yaitu dengan membandingkan antara nilai $t$ hitung dengan nilai $t$ tabel dari masing-masing variabel bebas. Nilai t hitung diperoleh dari hasil perhitungan uji t sedangkan $t$ tabel diperoleh dari tabel distribusi pada a $=5 \%$ dengan derajat kebebasan $(d f)$ n-k-1 atau 100-2-1=97. Diperoleh t tabel sebesar 1,660. Dari tabel 1 terlihat bahwa hasil pengujian hipotesis disiplin menunjukkan nilai t hitung sebesar 2.451 dengan taraf signifikansi 0,016. Taraf signifikansi tersebut lebih kecil dari 0,05 , yang berarti bahwa hipotesis dalam penelitian ini menolak Ho dan menerima Ha. Dengan demikian dapat berarti bahwa hipotesis "Disiplin mempunyai pengaruh terhadap Kinerja pegawai" diterima.

Dari tabel 1 terlihat bahwa hasil pengujian hipotesis Motivasi menunjukkan nilai t hitung sebesar 3.207 dengan taraf signifikansi 0,002. Taraf signifikansi tersebut lebih kecil dari 0,05, 
yang berarti bahwa hipotesis dalam penelitian ini menolak Ho dan menerima Ha. Dengan demikian dapat berarti bahwa hipotesis " Motivasi mempunyai pengaruh terhadap Kinerja pegawai " diterima.

\section{Kesimpulan}

1. Variabel bebas $(\mathrm{X})$ yaitu variabel disiplin (X) dan variabel motivasi (X2) berpengaruh terhadap variabel terikat ( $\mathrm{Y}$ ) yaitu kinerja pegawai pada Dinas Peternakan dan Kesehatan Hewan Provinsi Bengkulu. Nilai koefisien korelasi (R) sebesar 0,413 menunjukkan bahwa terdapat hubungan yang sedang antara variabel bebas (X1 dan X2) terhadap variabel kinerja (Y). Nilai $\mathrm{R}^{2}$ sebesar 0, 17 atau 17\% menunjukkan bahwa variabel bebas (X1dan X2) secara serentak berpengaruh $17 \%$ terhadap variabel kinerja $(\mathrm{Y})$ sedangkan sisanya sebesar 83\% dipengaruhi oleh variabel lain yang tidak diteliti dalam penelitian ini.

2. Setelah dilakukan uji $\mathrm{F}$ hitung 9,967 $>\mathrm{F}$ tabel 3,090 dengan tingkat signifikan $\alpha=0,05>$ 0,000. Maka dapat disimpulkan bahwa HO ditolak dan Ha diterima, artinya variabel disiplin dan motivasi berpengaruh terhadap kinerja pegawai Dinas Peternakan dan Kesehatan Hewan Provinsi Bengkulu.

3. Nilai t tabel sebesar 1,660, nilai $t$ hitung variabel disiplin sebesar 2.451 bila dibandingkan dengan $t$ tabel, maka $2.451>1,660$. Yang berarti disiplin berpengaruh terhadap kinerja pegawai. Nilai $t$ hitung variabel motivasi sebesar 3.207 bila dibandingkan dengan $t$ tabel, maka $3.207>1,660$. Hal ini berarti bahwa motivasi berpengaruh terhadap kinerja pegawai Dinas Peternakan dan Kesehatan Hewan Provinsi Bengkulu.

\section{Saran}

Hasil penelitian menunjukkan bahwa disiplin dan motivasi memiliki pengaruh yang sedang terhadap kinerja pegawai Dinas Peternakan dan Kesehatan Hewan Provinsi Bengkulu, sehingga pabila Dinas Peternakan dan Kesehatan Hewan Provinsi Bengkulu inigin lebih meningkatkan kinerja pegawainya maka perlu dicari faktor - faktor lain yang lebih mempengaruhi kinerja yang tidak di teliti dalam penelitian ini.

\section{DAFTAR PUSTAKA}

Dessler, Gary, 2010. Manajemen Sumber Daya Manusia. Indeks, Jakarta.

Abdurrahmat Fathoni. 2007. Manajemen Sumber daya Manusia. Rineka Cipta,. Jakarta.

Gomes, Faustino Cardoso, 2009, Manajemen Sumber Daya Manusia, Penerbit Andi. Yogyakarta

Azwar, Azrul. 1998. Pengantar Administrasi Kesehatan. Binarupa Aksara.Jakarta.

Handoko, T. Hani. 2008. Manajemen. BPFE, Yogyakarta

Hasibuan, Malayu SP, 2001, Manajemen Sumber Daya Dasar dan Kunci Keberhasilan (EdisiRevisi), Cetakan Ketiga, PT. Bumi Aksara, Jakarta.

Hasibuan, S.P Malayu, 1999. Organisasi dan Motivasi Dasar Peningkatan Produktifitas Bina Aksara, Bandung

Ilyas, Yaslis. 2001. Kinerja: Teori, Penilaian dan Penelitian. Pusat KajianEkonomi Kesehatan FKM.UI. Depok. Jakarta.

Malayu, Hasibuan. 1999. Manajemen Sumber Daya Manusia. Jakarta: PT Bumi Aksara. 
Mangkunegara, A.A. Anwar Prabu. 2001. Manajemen Sumber Daya Manusia Perusahaan. Remaja Rosdakarya, Bandung

Mangkunegara, Anwar, Prabu. 2000. Manajemen Sumber Daya Manusia. Remaja Rusdakarya, Bandung.

Mathis, Robert L dan Jackson, John H. 2002. Manajemen Sumber Daya Manusia. Salemba Empat, Jakarta.

Nitisemito, Alex S., 1996. Manajemen Personalia. Ghalia Indonesia, Jakarta

Prasetyo, Ristianti. 2006. Pengembangan Karier Sekretaris. Andi Yogyakarta, Yogyakarta.

Prijodarminto, Soegeng. 1994. Disiplin Kiat Menuju Sukses. Pradnya Paramita, Jakarta

Robbins, P, Stephen. 2006. Perilaku Organisasi. Edisi X. PT. Indeks. Jakarta

Sastrohadiwiryo, B, Siswanto. 2003. Manajemen Tenaga Kerja. Sinar Baru.Bandung.

Saydam, Gouzali. 1996. Manajemen Sumber Daya Manusia. Jilid I. PT. TokoGunung Agung. Jakarta.

Sedarmayanti, 2008, Manajemen Sumber Daya Manusia, Cetakan Pertama, PT. Refika Aditama, Bandung.

Sedarmayanti. 2005. Sumber Daya Manusia dan Produktivitas Kerja. CV. Mandar Maju, Bandung

Siagian, P, Sondang. 1996. Teori dan Praktek Kepemimpinan. Rineka Cipta.Jakarta.

Siagian, Sondang P, 2000, Manajemen Sumber Daya Manusia, Cetakan Kesembilan, BumiAksara, Jakarta.

Sudarwan, Danim, 2004, Motivasi Kepemimpinan dan Efektifitas Kelompok, Cetakan Pertama, Rineka Cipta, Jakarta.

Sugiyono, 2009,Statistik untuk Penelitian, Alfabeta, Bandung.

Sugiyono, 2012, Metode Penelitian Kuantitatif Kualitatif dan R\&B. Alfabeta, Bandung

The Liang Gie, 1981. Administrasi Perkantoran Modern. Liberty, Yogyakarta

Veithzal R dan Fauzi. D Ahmad. 2004. Performance Appraisal. Alfabeta.Bandung

Wibowo. 2009. Manajemen Kinerja. Edisi ke 2. Rajawali Pers. Jakarta

Winardi. 2007. Motivasi dan Pemotivasian Dalam Manajemen. Edisi IV. RajaGrafindo Persada. Jakarta.

Wursanto, 1987. Manajemen Kepegawaian. Kanisius, Yogyakarta 